\title{
THE INFLUENCE OF SHORT DURATION EXERCISE ON THE CONCENTRATION OF C-REACTIVE PROTEIN AND SELECTED HAEMATOLOGICAL AND BIOCHEM- ICAL PARAMETERS IN THE BLOOD OF GERMAN SHEPHERD DOGS
}

\author{
Goldírová, K. ${ }^{1}$, Fialkovičová, M. ${ }^{1}$, Benková, M. $^{2}$ \\ Tóthová, C. ${ }^{3}$, Harčárová, M. ${ }^{4}$ \\ ${ }^{1}$ Small Animals Clinic, University of Veterinary Medicine and Pharmacy, Košice \\ ${ }^{2}$ Faculty of Mining, Ecology, Process Control and Geotechnology, Technical University, Košice \\ ${ }^{3}$ Clinic for Ruminants, ${ }^{4}$ Department of Pharmacology and Toxicology \\ University of Veterinary Medicine and Pharmacy, Košice, \\ Slovakia
}

goldirovakatka@gmail.com

\section{ABSTRACT}

Short-term intensive exercise may be associated with many short-lasting metabolic changes. These changes depend on the duration and intensity of the exercise. The aim of our study was to determine potential changes in C-reactive protein (CRP) and selected haematological and biochemical parameters in clinically healthy German shepherd dogs before short duration high-intensity exercise and 6 hours after the exercise. During the study, the dogs were subjected to the following defensive training: detaining a figurant running away from a dog $(2 \times)$ and detaining with a counterattack $(2 \times)$. The running distance was $200 \mathrm{~m}$ at a mean speed of $28 \mathrm{~km} \cdot \mathrm{h}^{-1}$. The investigation of haematological parameters revealed a significant decrease in the mean values of platelet haematocrit (PCT) 6 hours after the training. Significant differences in the levels determined before and after exercise were observed also for phosphorus (P) and for iron (Fe). At the same time, we observed a significant increase in the mean calcium (Ca) level and a significant decrease in sodium $(\mathrm{Na})$ and chlorides $(\mathrm{Cl})$. The activity of aspartate aminotransferase (AST) significantly increased after exercise. Concentrations of acute phase $\mathrm{C}$-reactive proteins were increased 6 hours after exercise in comparison to those before exercise but the difference was insignificant. Although the concentration of CRP was increased insignificantly after the exercise, when interpreting concentrations of this nonspecific indicator of inflammation, one should keep in mind that intensive exercise may also affect its concentrations.

Key words: dog; exercise; C-reactive protein; blood parameters

\section{INTRODUCTION}

Intensive physical exercise can be associated with a number of short-term metabolic changes, including changes in glucose homeostasis and disturbances of electrolyte and acid-base balance [21]. These changes depend on several factors, such as intensity and length of the challenge, condition of the animal, thermoregulation and at- 
mospheric conditions [16]. Many authors have described organ system changes during exercise and investigated the time needed for returning the exercise-altered parameters back to the quiescent level. Changes in serum concentrations of biochemical parameters and acute phase proteins were described in sled dogs [2]. Acute phase response (APR) is a rapid inherent protective mechanism of the organism developing before stimulation of specific immune response that limits damage to tissues. APR supports restoration of homeostasis. The APR triggering stimuli include: trauma, infection, stress, neoplasia or inflammation $[5,12]$. APR is characterised by a number of various systemic influences, such as: fever, leukocytes, changes in the concentrations of hormones and mineral elements, and metabolic changes [7]. APR is also associated with changes in the level of acute phase proteins (APP) [3]. C-reactive protein (CRP) is the most sensitive acute phase protein in dogs [11]. In these animals, the increase in CRP is more rapid than in humans. After the stimulation, increased levels of CRP can be detected for the first time after 4 hours and maximum levels of this parameter are detected after approximately 24 hours. Contrary to this, the increase in CRP in humans is generally detected 6 hours after the stimulus and its maximum levels are reached after 48 hours. The half-time of CRP break-down is relatively short and it occurs after about $6-8$ hours $[4,13,14]$. Some biological factors may affect the level of APP in dogs, such as: breed, pregnancy, nutrition status, environment, some medicines, and physical exercise $[3,9]$. Increase in the concentrations of CRP in dogs observed during systemic inflammatory response is difficult to distinguish from that induced by intensive physical activity [22]. Although greyhound and sled dog races are the best known dog sports, dog athletes can compete in a range of other sports.

The aim of our study was to investigate the potential changes in haematological and biochemical parameters in German shepherd dogs involved in sport and defence training.

\section{MATERIALS AND METHODS}

We investigated a group of 10 healthy German shepherd dogs ( 9 bitches and 1 male, 2-6 years old). Before the investigation, all dogs were examined clinically, were afebrile and exhibited normal quiescent values of respiration rates and pulse. Samples of blood were collected from vena cephalica antebrachii before a short duration high-intensity exercise and 6 hours after the exercise. The dogs were not exposed to physical exertion for 48 hours before the first blood sampling. The relevant biochemical and haematological parameters were determined in the blood of the dogs.

During the study, the dogs were subjected to the following defensive training: detaining a fugitive running away from a dog $(2 \times)$ and detaining with a counterattack $(2 \times)$. The running distance was $200 \mathrm{~m}$ at a mean speed of $28 \mathrm{~km} \cdot \mathrm{h}^{-1}$.

The haematological examinations included the determination of the following parameters: erythrocytes (RBC), leukocytes (WBC), concentration of haemoglobin (HGB), haematocrit (HCT), mean corpuscular volume (MCV), mean corpuscular haemoglobin $(\mathrm{MCH})$, mean concentration of haemoglobin in erythrocytes (MCHC), distribution curve of erythrocytes (RDW), reticulocytes (RETIC), neutrophils (NEU), lymphocytes (LYM), monocytes (MONO), eosinophils (EOS), basophils (BASO), thrombocytes (platelets - PLT), mean platelet volume (MPV), platelet distribution width (PDW), and platelet haematocrit (PCT). The haematological parameters were determined employing an automatic haematological analyser ABX Micros ABC Vet (Horiba Medical, France).

The biochemical examinations involved: determination of C-reactive protein (CRP), calcium (Ca), magnesium $(\mathrm{Mg})$, phosphorus $(\mathrm{P})$, sodium $(\mathrm{Na})$, potassium $(\mathrm{K})$, chlorides $(\mathrm{Cl})$, iron $(\mathrm{Fe})$, aspartate aminotransferase (AST), alanine aminotransferase (ALT), gamma-glutamyl transferase (GGT), alkaline phosphatase (ALP), lactate dehydrogenase $(\mathrm{LDH})$, pancreatic amylase (pAMS), glucose (GLU), total cholesterol (TCHOL), triglycerides(TG), total bilirubin (TBil), albumin (ALB), creatinine (CREAT) and urea (UREA).

The C-reactive protein was determined by enzymatic immuno-analysis using commercial ELISA tests (Tridelta Development, Ireland). Serum samples were diluted 1:500. The intensity of the colour reaction was evaluated spectrophotometrically at $450 \mathrm{~nm}$ by means of an automatic photometer Opsys MR (Dynex Technologies, USA), with $630 \mathrm{~nm}$ as a reference value. Other biochemical parameters were determined employing a biochemical analyser Cobas c111 (Roche, Switzerland).

All statistical and database operations were performed with the help of a personal computer using a table proces- 
sor Excel (Microsoft, USA) and the following tests: Grubbs test, Bartlett test, and one and two factor analysis of variance ANOVA. The level of statistical significance was set to $\mathrm{P}<0.05$

\section{RESULTS}

The investigation of haematological parameters showed a significant decrease in the mean values of PCT 6 hours after the training (from $0.32 \pm 0.08 \%$ to $0.25 \pm 0.06 \%$; $\mathrm{Ta}$ ble 2, Fig. 1). Significant differences $(\mathrm{P}<0.05)$ in the levels determined before and after exercise were observed also for phosphorus, which increased from $1.13 \pm 0.19$ to $1.38 \pm 0.10 \mathrm{mmol}^{-1} \mathrm{l}^{-1}$ (Table 2, Fig. 4), and for iron which decreased from $21.41 \pm 10.38$ to $19.37 \pm 5.19 \mathrm{mmol}^{-1}$ (Table 2, Fig. 5). At the same time, we observed a significant increase $(\mathrm{P}<0.05)$ in the mean calcium level from $1.87 \pm 0.17$ to $2.16 \pm 0.12 \mathrm{mmol}^{-\mathrm{l}^{-1}}$ (Table 2, Fig. 3 ) and a significant decrease $(\mathrm{P}<0.05)$ in sodium from $140.97 \pm 1.69$ to $137.12 \pm 1.76 \mathrm{mmol}^{-1} \mathrm{l}^{-1}$ ) (Table 2) and chlorides from $110.75 \pm 2.51$ to $107.78 \pm 2.25 \mathrm{mmol}^{-1} \mathrm{l}^{-1}$ (Table 2). The activity of AST significantly increased from $0.40 \pm 0.08$ to $0.48 \pm 0.09 \mu$ kat. $^{-1}$ (Table 2, Fig. 6). The concentrations of the acute phase $\mathrm{C}$-reactive proteins were increased 6 hours after exercise $(45.00 \pm 13.37)$ in comparison to those before exercise $\left(40.69 \pm 16.48 \mathrm{mg} . \mathrm{l}^{-1}\right)$, but the difference was insignificant (Table 1, Fig. 2). The results of other parameters presented in Tables 1 and 2 showed no significant differences in the other concentrations or activities.

Table 1. Haematological parameters and concentrations of C-reactive protein in the blood of German shepherd dogs before and after exercise

\begin{tabular}{|c|c|c|c|c|c|}
\hline \multirow{3}{*}{ Parameter } & & \multirow{2}{*}{\multicolumn{2}{|c|}{ Before exercise }} & \multicolumn{2}{|c|}{ After exercise } \\
\hline & & & $n=10$ & \multicolumn{2}{|c|}{$n=10$} \\
\hline & & $x$ & $\pm \mathrm{SD}$ & $x$ & $\pm \mathrm{SD}$ \\
\hline \multirow{18}{*}{$\begin{array}{l}\text { Haematological } \\
\text { parameters }\end{array}$} & $\mathrm{HGB}\left[\mathrm{g} \cdot \mathrm{dl}^{-1}\right]$ & 14.40 & 1.49 & 14.06 & 1.69 \\
\hline & $\operatorname{RBC}\left[{\left.\mathrm{T} . \mathrm{I}^{-1}\right]}^{-1}\right.$ & 6.45 & 0.73 & 6.31 & 0.88 \\
\hline & WBC $\left[G . I^{-1}\right]$ & 11.87 & 3.73 & 12.23 & 2.81 \\
\hline & $\operatorname{MCV}\left[\mathrm{f} . \mathrm{I}^{-1}\right]$ & 66.77 & 2.58 & 63.64 & 2.77 \\
\hline & HCT [l..$\left.^{-1}\right]$ & 43.19 & 4.86 & 41.52 & 5.71 \\
\hline & $\mathrm{MCH}[\mathrm{pg}]$ & 22.38 & 1.15 & 22.33 & 1.13 \\
\hline & $\mathrm{MCHC}\left[\mathrm{g} \cdot \mathrm{dl}{ }^{-1}\right]$ & 33.53 & 0.83 & 33.93 & 0.94 \\
\hline & RDW [\%] & 18.81 & 1.56 & 16.03 & 1.83 \\
\hline & RETIC $\left[K .\left.\mu\right|^{-1}\right]$ & 32.37 & 21.50 & 30.32 & 19.66 \\
\hline & $\operatorname{NEU}\left[\times 10^{9} . .^{-1}\right]$ & 6.61 & 1.35 & 7.96 & 2.11 \\
\hline & $\operatorname{LYM}\left[\times 10^{9} . .^{-1}\right]$ & 2.06 & 0.45 & 2.26 & 0.70 \\
\hline & MONO $\left[\times 10^{9} . .^{-1}\right]$ & 1.00 & 0.50 & 1.02 & 0.40 \\
\hline & $\operatorname{EOS}\left[\times 10^{9} . I^{-1}\right]$ & 1.00 & 0.30 & 0.96 & 0.40 \\
\hline & BASO $\left[\times 10^{9} . I^{-1}\right]$ & 0.04 & 0.02 & 0.04 & 0.03 \\
\hline & PLT $\left[K . \mu l^{-1}\right]$ & 218.00 & 110.81 & 196.00 & 73.47 \\
\hline & MPV [f]] & 11.67 & 0.76 & 11.78 & 0.66 \\
\hline & PDW [f]] & 15.50 & 1.94 & 15.91 & 1.64 \\
\hline & РСТ [\%] & 0.32 & $0.08^{*}$ & 0.25 & $0.06^{*}$ \\
\hline Specific protein & CRP $\left[\mathrm{mg} . \mathrm{l}^{-1}\right]$ & 40.69 & 16.48 & 45.00 & 13.37 \\
\hline
\end{tabular}

* - Significant at $\mathrm{P}<0.05$

HGB - haemoglobin; RBC - erythrocytes; WBC - leukocytes; MCV - mean corpuscular volume; HCT — haematocrit; MCH - mean corpuscular haemoglobin; MCHC - mean concentration of haemoglobin in erythrocytes; RDW - distribution curve of erythrocytes; RETIC - reticulocytes; NEU — neutrophils; LYM - lymphocytes; MONO - monocytes; EOS - eosinophils; BASO - basophils; PLT — thrombocytes (platelets); MPV — mean platelet volume; PDW — platelet distribution width; PCT — platelet haematocrit; CRP — C-reactive protein 
Table 2. Concentration of electrolytes and minerals and enzyme activity in the blood of German shepherd dogsbefore and after exercise

\begin{tabular}{|c|c|c|c|c|c|}
\hline \multirow{3}{*}{ Parameter } & & \multicolumn{2}{|c|}{ Before exercise } & \multicolumn{2}{|c|}{ After exercise } \\
\hline & & \multicolumn{2}{|c|}{$\mathrm{n}=10$} & \multicolumn{2}{|c|}{$\mathrm{n}=10$} \\
\hline & & $\mathrm{x}$ & $\pm \mathrm{SD}$ & $\mathrm{x}$ & $\pm \mathrm{SD}$ \\
\hline \multirow{7}{*}{$\begin{array}{l}\text { Electrolytes and } \\
\text { minerals }\end{array}$} & $\mathrm{Ca}\left[\mathrm{mmol} . \mathrm{I}^{-1}\right]$ & $1.87^{*}$ & 0.17 & $2.16^{*}$ & 0.12 \\
\hline & $\mathrm{Mg}\left[\mathrm{mmo} . \mathrm{l}^{-1}\right]$ & 0.66 & 0.08 & 0.67 & 0.07 \\
\hline & $\mathrm{P}\left[\mathrm{mmol} . \mathrm{I}^{-1}\right]$ & $1.13^{*}$ & $0.19^{*}$ & $1.38^{*}$ & $0.10^{*}$ \\
\hline & $\mathrm{Na}\left[\mathrm{mmol} . \mathrm{I}^{-1}\right]$ & $140.97^{*}$ & 1.69 & $137.12^{*}$ & 1.76 \\
\hline & $\mathrm{K}\left[\mathrm{mmol}^{\mathrm{I}} \mathrm{I}^{-1}\right]$ & 5.53 & 0.85 & 5.05 & 0.29 \\
\hline & $\mathrm{Cl}\left[\mathrm{mmol} . \mathrm{I}^{-1}\right]$ & $110.75^{*}$ & 2.51 & $107.78^{*}$ & 2.25 \\
\hline & $\mathrm{Fe}\left[\mu \mathrm{mol} . \mathrm{I}^{-1}\right]$ & 21.41 & $10.38^{*}$ & 19.37 & $5.19^{*}$ \\
\hline \multirow{6}{*}{ Enzyme activity } & AST $\left[\mu\right.$ kat..$\left.^{-1}\right]$ & $0.40^{*}$ & 0.08 & $0.48^{*}$ & 0.09 \\
\hline & ALT [ $\left[\right.$ kat..$\left.^{-1}\right]$ & 0.77 & 0.93 & 0.67 & 0.74 \\
\hline & GGT [ $\mu$ kat...$\left.^{-1}\right]$ & 0.10 & 0.04 & 0.12 & 0.03 \\
\hline & $\operatorname{ALP}\left[\mu k_{\text {kat. }} .^{-1}\right]$ & 0.75 & 0.33 & 0.70 & 0.32 \\
\hline & $\mathrm{pAMS}\left[\mu \mathrm{kat} / \mathrm{I}^{-1}\right]$ & 7.83 & 1.85 & 7.71 & 1.78 \\
\hline & LDH $\left[\mu\right.$ kat. $^{\left.-I^{-1}\right]}$ & 0.91 & 0.43 & 1.16 & 0.84 \\
\hline
\end{tabular}

Table 3. Concentration of metabolites and lipids in the blood of German shepherd dogs after exercise

\begin{tabular}{|c|c|c|c|c|c|}
\hline \multirow{3}{*}{ Parameter } & & \multicolumn{2}{|c|}{ Before exercise } & \multicolumn{2}{|c|}{ After exercise } \\
\hline & & \multicolumn{2}{|c|}{$n=10$} & \multicolumn{2}{|c|}{$n=10$} \\
\hline & & $x$ & $\pm \mathrm{SD}$ & $\mathrm{x}$ & $\pm \mathrm{SD}$ \\
\hline \multirow{5}{*}{ Metabolites } & ALB $\left[\mathrm{g} . \mathrm{I}^{-1}\right]$ & 29.56 & 2.91 & 29.74 & 3.01 \\
\hline & CREAT $\left[\mu \mathrm{mol} \mathrm{I}^{-1}{ }^{-1}\right]$ & 51.38 & 8.06 & 51.10 & 8.80 \\
\hline & UREA [mmol//-1'] & 3.65 & 1.35 & 3.45 & 1.21 \\
\hline & TBIL $\left[\mu \mathrm{mol}^{\left.-I^{-1}\right]}\right.$ & 1.63 & 0.68 & 1.58 & 0.49 \\
\hline & $\mathrm{GLU}\left[\mathrm{mmol} . \mathrm{I}^{-1}\right]$ & 3.31 & 0.30 & 3.18 & 0.29 \\
\hline \multirow{2}{*}{ Lipids } & TCHOL $\left[\mathrm{mmol}^{\left.-\mathrm{I}^{-1}\right]}\right.$ & 3.93 & 0.71 & 3.91 & 0.61 \\
\hline & $\mathrm{TG}\left[\mathrm{mmol} . \mathrm{I}^{-1}\right]$ & 0.41 & 0.14 & 0.39 & 0.11 \\
\hline
\end{tabular}

ALB - albumin; CREAT — creatinine;UREA - urea; TBIL — total bilirubin

GLU — glucose; TCHOL — total cholesterol; TG — triglycerides 


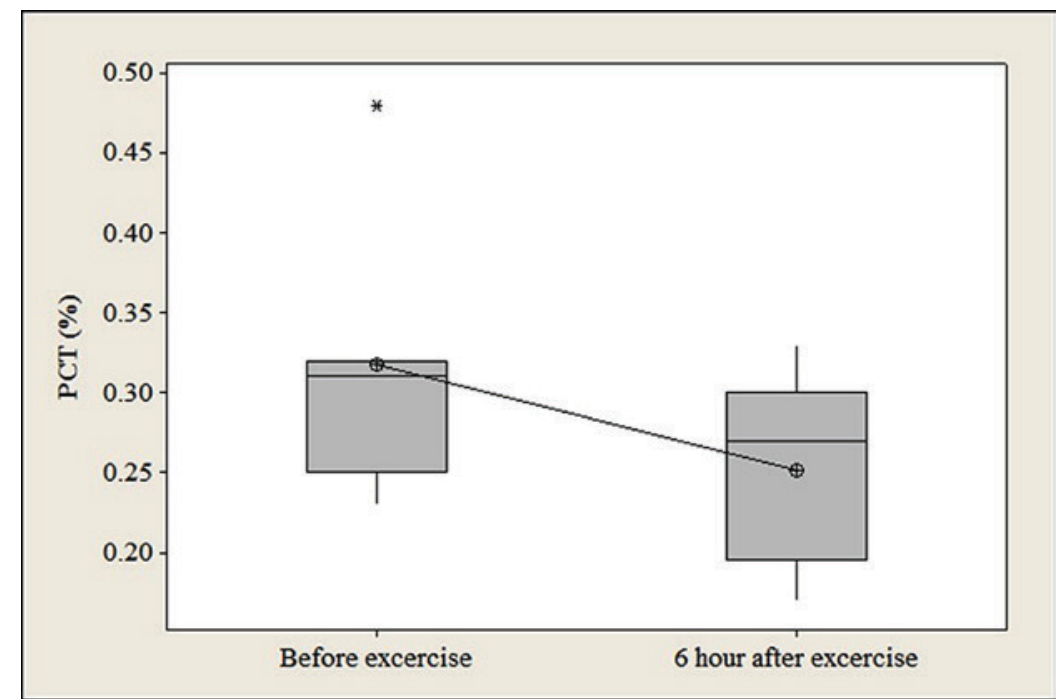

Fig. 1. Changes in platelet haematocrit $(\mathrm{PCT})$ in the blood of German shepherd dogs 6 hours after exercise, ${ }^{*}-(\mathrm{P}<0.05)$

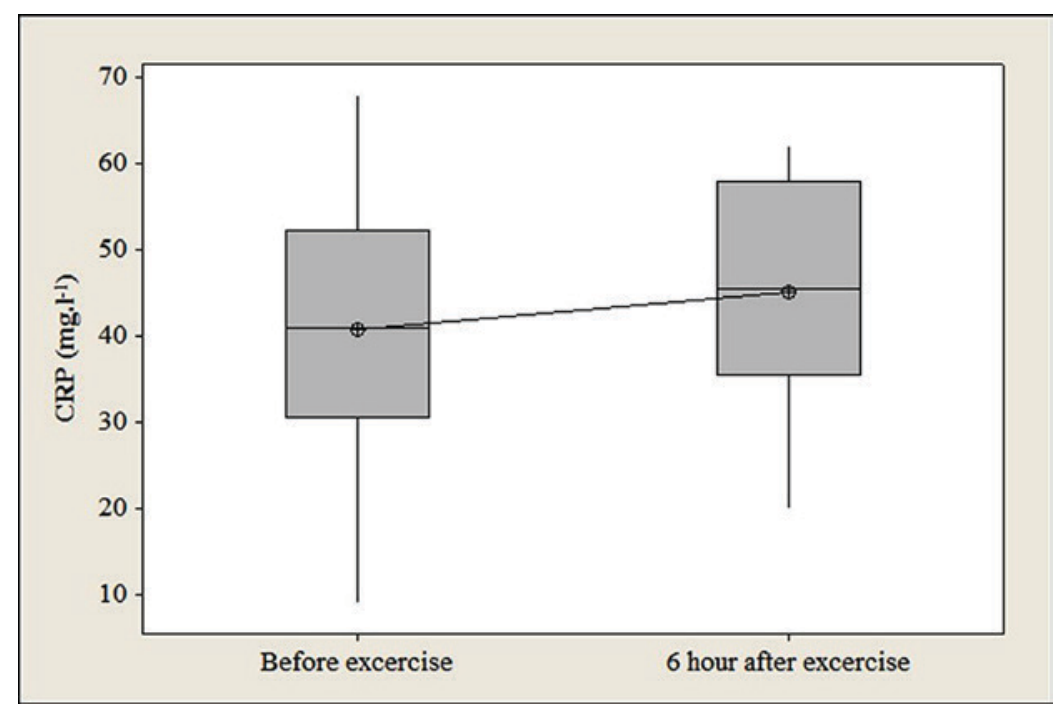

Fig. 2. Changes in concentration of c-reactive protein (CRP) in the blood of German shepherd dogs 6 hours after exercise

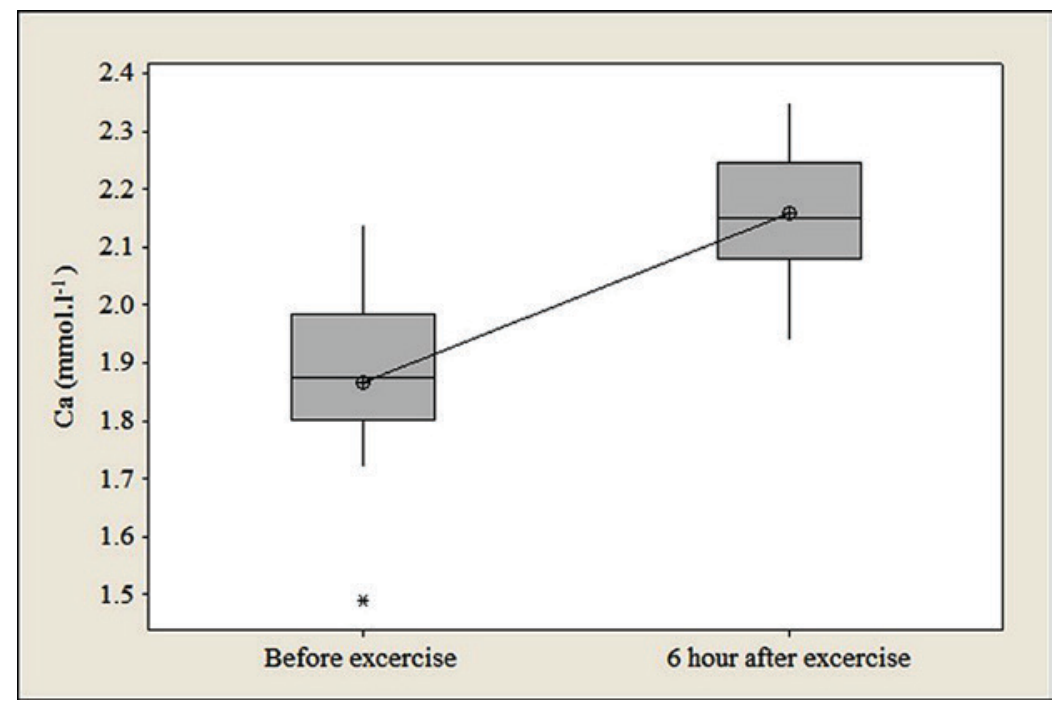

Fig. 3. Changes in the concentration of calcium in the blood of German shepherd dogs 6 hours after exercise 


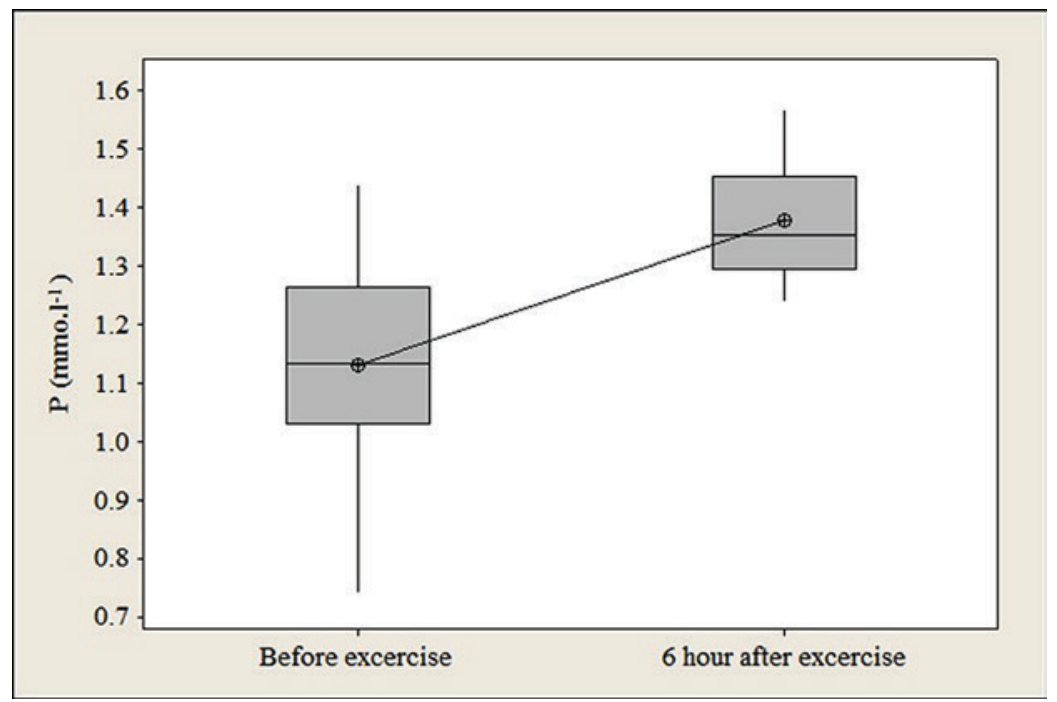

Fig. 4. Changes in concentration of phosphorus in the blood of German shepherd dogs 6 hours after exercise

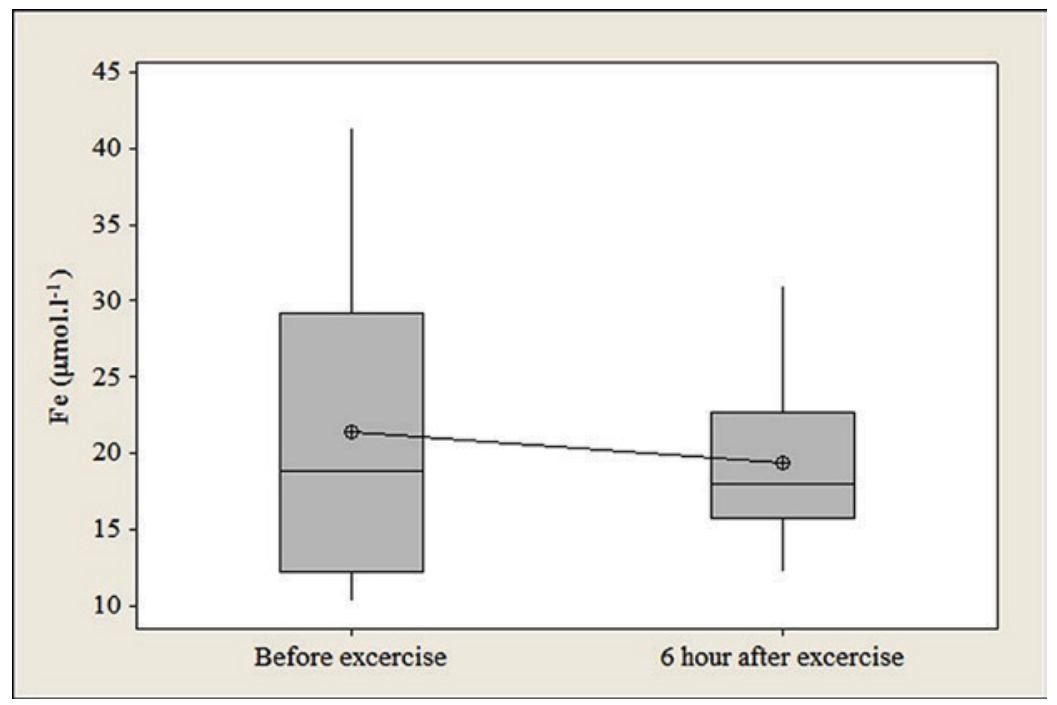

Fig. 5. Changes in concentration of iron in the blood of German Shepherd dogs 6 hours after exercise

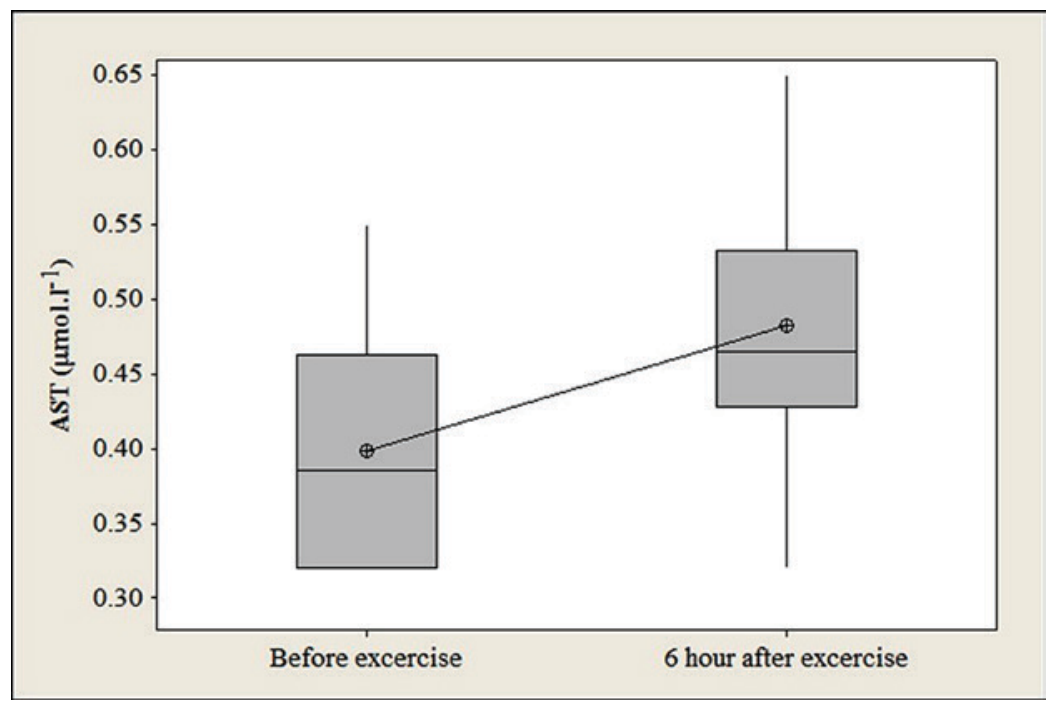

Fig. 6. Changes in the activity of aspartate aminotransferase (AST) in the blood of German shepherd dogs 6 hours after exercise 


\section{DISCUSSION}

High-intensity exercise results in many short-term metabolic changes including altered glucose homeostasis and electrolyte and acid-base imbalance. The degree of such changes is affected by the intensity and duration of physical activity [22]. Casela et al. described changes in CRP in hunting dogs after 3 hours of physical activity during hunts. These dogs exhibited significantly increased CRP levels [2]. Such changes agree with those reported by other authors who pointed to the role of the acute phase proteins not only in association with inflammatory processes, but also in situations not related to inflammation, when the animals are exposed to stress factors.

In our study we detected increased levels of CRP 6 hours after exercise (Table 1, Fig. 2), however, the increase was insignificant. It should be mentioned that the examination of blood samples before exercise showed that haematological and biochemical parameters in the clinically healthy dogs were within the reference range except for CRP which exceeded the reference limit $\left(\mathrm{CRP}<20 \mathrm{mg} . \mathrm{l}^{-1}\right)$. This may be ascribed to the regular training of these dogs. The levels of CRP determined after high-intensity exercise were higher than those observed at inflammatory processes associated with infectious diseases. Wakshlag et al. reported that despite increased levels of CRP in dogs, these animals did not show an increase in IL-6 compared to the basal level [21]. A study in people demonstrated that after $25 \mathrm{~km}$ runs in 4 subsequent days, the CRP levels were increased on days 3 and 5 but no changes were observed in components of $\mathrm{C} 3$ and C4 complements [8]. Studies in humans also found a decrease in HGB and HCT in athletes in comparison with untrained persons, between periods of rest and training seasons and between beginning and completion of races [8, 19]. In athletes during training, particularly for endurance races, a decrease in HCT was described due to increase in plasma volume referred to as "sport anaemia". This increase in plasma volume in trained individuals is most likely caused by aldosterone-dependent renal reabsorption of sodium and retention of water. This occurs due to an increase in antidiuretic hormone as a compensatory mechanism of fluid losses during physical challenge [10]. A decrease in HGB and HCT was described also in sled dogs during training and racing $[6,15]$. Our study also showed a decrease in the levels of HGB and HCT after exercise (Table 1). Angle et al., Rovira et al. and Tharwat et al., failed to observe changes in haematological parameters in dogs during exercise $[1,17,20]$. The slight decrease in RBC observed in our study was insignificant (Table 1). A different way of training, type and exercise duration could also affect the results of RBC. It is important to consider also the time of blood sampling as the altered haematological parameters may return to their initial level as soon as $5-10$ minutes after termination of the physical activity [1]. Leukocytosis appears to be a physiological response of dogs to physical challenge. Such response was described in sled dogs after short races although no changes in WBC were reported after agility races. It was assumed that an increase in WBC after exercise is caused by mobilisation of WBC subpopulations from peripheral reserves. These changes arise due to activation of soluble molecules released as a result of damage to muscle mass, hormonal changes (particularly influence of catecholamines) and oxidation stress. Rovir a et al. reported increased levels of WBC in horses associated with mobilisation of lymphocyte-rich blood from the spleen [17]. The moderate increase in WBC observed in our study agreed with the results of Rovira at al. who observed physiological, blood and endocrine parameters in search and rescue-trained dogs (20 min training) (Table 1) [17]. Angle et al. reported significantly higher concentrations of $\mathrm{Na}, \mathrm{K}, \mathrm{Ca}$ and ALB in samples collected from sled dogs before short duration high-intensity exercise [1]. The observations by Rovira at al. indicated a decrease in sodium at 5 and 15 minutes after exercise. After 30 minutes, the levels of $\mathrm{Na}$ returned back to those before exercise and, at the same time, a gradual decrease in $\mathrm{Cl}$ was observed in these dogs [17]. Our study showed a decrease in $\mathrm{K}, \mathrm{Na}$ and $\mathrm{Cl}$ after exercise but contrary to the above shifts, $\mathrm{Ca}$ and ALB were increased at 6 hours after exercise. The mean concentrations of Fe significantly differed at individual samplings before and after the exercise. The concentration of Fe before exercise $\left(21.41 \pm 10.38 \mu \mathrm{mol}^{-\mathrm{l}^{-1}}\right)$ slightly exceeded the upper reference limit for this element (Fe 16$\left.21 \mu \mathrm{mol} . \mathrm{l}^{-1}\right)$, but six hours after exercise it was decreased to $19.37 \pm 5.19 \mu \mathrm{mol} . \mathrm{l}^{-1}$ (Table 2, Fig. 5). W akshlag et al. reported only a slight decrease in the concentration of $\mathrm{Fe}$ (15\%) in dogs after exercise compared to changes in this parameter in humans (50\%), however, the diet of the dogs was rich in Fe [21]. Normally, most of the catabolism of damaged RBC takes place in the spleen and liver where endothelial phagocytosis of RBC occurs. Iron from the cells is incorporated in ferritin. A portion of RBC is eliminated 
also in vessels during circulation. HGB released during haemolysis is subsequently bound in a complex with haptoglobin. Iron from this haemolysis does not bind to ferritin but is released to plasma in the form of ferrous ions. During exercise, oversaturation of haptoglobin develops, which prevents additional binding of haemoglobin. When the haemoglobin-binding capacity of haptoglobin is exceeded, haemoglobin is released through glomeruli into the urine and haemoglobinuria may develop [18].

\section{CONCLUSIONS}

Our results indicate that high-intensity short duration exercise induced significant changes in concentrations of $\mathrm{Ca}, \mathrm{P}, \mathrm{Na}, \mathrm{K}, \mathrm{Cl}, \mathrm{Fe}, \mathrm{PCT}$ and AST in German shepherds. Rapid increase in concentration of APP after exercise and subsequent rapid decline during the quiescent phase when the animals were not exposed to additional stimulus, makes it possible to use APP as a biomarker for routine screening of health and condition of these animals. When evaluating the levels of CRP as a non-specific indicator of inflammation, one should consider the fact that intensive exercise can also affect the level of this parameter.

\section{REFERENCES}

1. Angle, C. T., Wakshlag, J. J., Gillette, R. L., Stokol, T., Geske, S., Adkins, T.O., Gregor, C., 2009: Haematologic, serum biochemical and cortisol changes associated with anticipation of exercise and short duration high-intensity exercise in sled dogs. Veterinary Clinical Pathology, 38, 370-374.

2. Casella, S., Fazio, F., Russo, C., Giudice, E., Piccione, G., 2013: Acute phase proteins response in hunting dogs. J. Vet. Diagn. Invest., 25, 577-580.

3. Cerón, J.J., Eckersall, P.D., Martínez-Subiela, S. 2005: Acute phase proteins in dogs and cats: current knowledge and future perspectives. Veterinary Clinical Pathology, 34, 85-99.

4. Conner, J.G., Eckersall, P.D., Ferguson, J., 1988: Acute phase response in the dog following surgical trauma. Research in Veterinary Science, 45, 107-110.

5. Cray, C., Zaias, J., Altman, N.H., 2009: Acute phase response in animals: A review. American Association for Laboratory Animal Science, 59, 517-526.
6. Davis, M.S., Davis, W.C., Ensign, W.Y., Hinchcliff, K. W., Holbrook, T. C., Williamson, K. K., 2008: Effects of training and stenuous exercise on hematologic values and peripheral blood leukocyte subsets in racing sled dogs. J. Am. Vet. Med. Assoc., 232, 873-878.

7. Eckersall, P.D., 2000: Recent advances and future prospects for the use of acute phase proteins as markers of disease in animals. Revue de Medicine Vétérinaire, 151, 577-584.

8. Fallon, K.E., 2001: The acute phase response and exercise: the ultramarathon as prototype exercise. Clinical Journal of Sport Medicine, 11, 38-43.

9. Kenyon, C.H., Basaraba, R. J., Bohn, A.A., 2011: Influence of endurance exercise on serum concentrations of iron and acute phase proteins in racing sled dogs. J. Am. Vet. Med. Assoc., 239, 1201-1210.

10. Mairbäurl, H., 2013: Red blood cells in sports: effect of exercise and training on oxygen supply by red blood cells. Frontiers in Physiology, 4, 332.

11. McClure, V., van Schoor, M., Thompson, P. N., KjelgaardHansen, M., Goddard, A., 2013: Evaluation of the use of serum C-reactive protein concentration to predict outcome in puppies infected with canine parvovirus. J. Am. Vet. Med. Assoc., 243, 361-366.

12. McGrotty, Y.L., Knottenbelt, C.M., Ramsey, I.K., Reid, S. W., Eckersall, P.D., 2003: Haptoglobin concentrations in a canine hospital population. Vet. Rec., 152, 562-564.

13. McGrotty, Y.L., Knottenbelt, C.M., Ramsey, I.K., Reid, S. W., Eckersall, P.D., 2004: Evaluation of a rapid assay for canine C-reactive protein. Vet. Rec., 154, 175-176.

14. Pepys, M.B., Hirschfield, G.M., 2003: C-reactive protein: a critical update. J. Clin. Invest., 111, 1805-1812.

15. Querengaesser, A., Iben, C., Leibetseder, J., 1994: Blood changes during training and racing in sled dogs. J. Nutr., 124, $2760-2764$.

16. Rovira, S., Muňoz, A., Benito, M., 2007: Fluid and electrolyte shifts during and after agility competitions in dogs. J. Vet. Med. Sci., 69, 31-35.

17. Rovira, S., Muňoz, A., Benito, M., 2008: Effect of exercise on physiological, blood and endocrine parameters in search and rescue-trained dogs. Vet. Med., 53, 333-346.

18. Rother, R. P., Bell, L., Hillmen, P., Gladwin, M. T., 2005: The clinical sequelae of intravascular haemolysis and extracellular plasma haemoglobin: a novel mechanism of human disease. J. Am. Vet. Med. Assoc., 293, 1653-1662.

19. Shaskey, D. J., Green, G. A., 2000: Sports haematology. Sports Medicine, 91, 27-38. 
20. Tharwat, M., Al-Sobayil, F., Buczinski, S., 2014: Influence of racing on the serum concentrations of acute-phase proteins and bone metabolism biomarkers in racing greyhounds. Vet. J., 202, 372-377.

21. Wakshlag, J.J., Kraus, M.S., Gelzer, A.R., Downey, R.I., Vacchani, P., 2010: The influence of high-intensity moderate duration exercise on cardiac troponin I and C-reactive protein in sled dogs. J. Vet. Intern. Med., 24, 1388-1392.
22. Wakshlag, J. J., Stokol, T., Geske, S. M., Greger, C. E., Angle, C.T., Gillette, R.I., 2010: Evaluation of exercise-induced changes in concentrations of C-reactive protein and serum biochemical values in sled dogs completing a long-distance endurance race. Am. J. Vet. Res., 71, 1207-1213.

Received April 27, 2017

Accepted May 9, 2017 